The Informal Company Law Expert Group (ICLEG)

\title{
Report on
}

\section{information on}

\section{groups}

March 2016 
The Informal Company Law Expert Group (ICLEG) was established by the European Commission (EC) in May 2014 to assist it with expert advice on issues of company law and it held its first meeting on 26 June 2014. The agendas of its meetings are available online at the webpage maintained by the $\mathrm{EC}^{1}$.

The members of ICLEG are:

1. ARMOUR John

2. BARTKUS Gintautas

3. CLARKE Blanaid

4. CONAC Pierre-Henri

5. DE KLUIVER Harm-Jan

6. FLEISCHER Holger

7. FUENTES NAHARRO Mónica

8. HANSEN Jesper Lau

9. KNAPP Vanessa

10. LAMANDINI Marco

11. RADWAN Arkadiusz

12. TEICHMANN Christoph

13. VAN HET KAAR Robbert

14. WINNER Martin

On 26 January 2015, the EC requested ICLEG to consider the issue of information on groups. In response to this call one member, Martin Winner, was charged with producing a report on behalf of the Group. After consultation within the Group, this report reflects the advice of ICLEG to the EC as to matters that ICLEG believe merit further consideration.

${ }^{1}$ http://ec.europa.eu/justice/civil/company-law/index en.htm 
Disclaimer: As this paper has been drafted by ICLEG, it solely reflects the views of the Group. It should not in any way be interpreted as representing the views of the EC. It should also be noted that the report purports to present a range of ideas that can inspire the EC in its further possible work on group companies. We have not considered whether these ideas are politically feasible and the range of ideas, opinions and recommendations are not necessarily supported by each and every member of the Group, although in general we believe that they are worthy of serious consideration and further consultation with other interested parties. We generally believe that it is important to prepare any legislative initiative by detailed consultation with the affected parties, notably companies, investors and public authorities, and we recommend that this be done to the greatest extent possible both on the general principles and, once the general principles have been established, on detailed proposals for any action. 


\section{Contents}

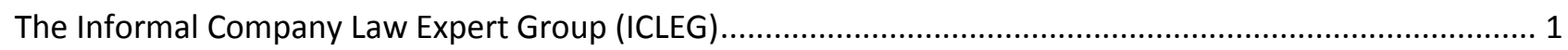

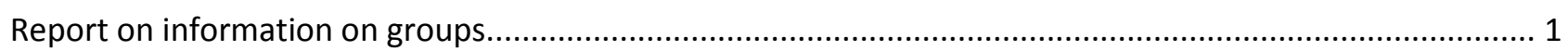

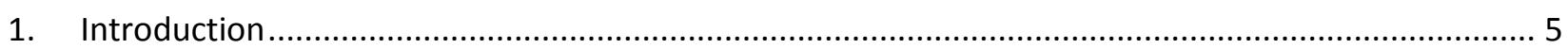

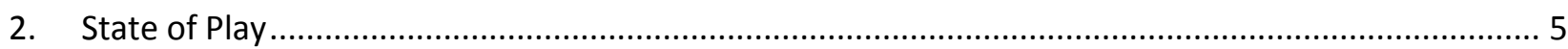

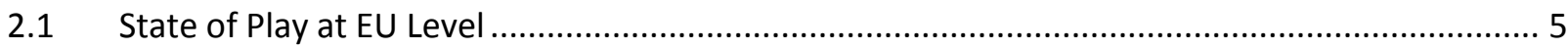

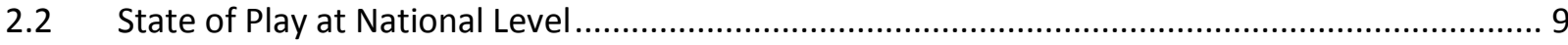

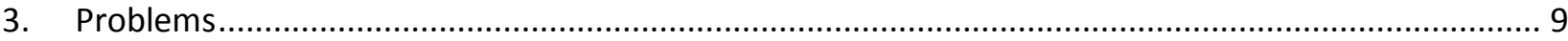

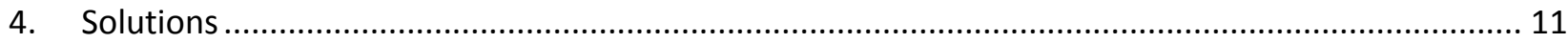

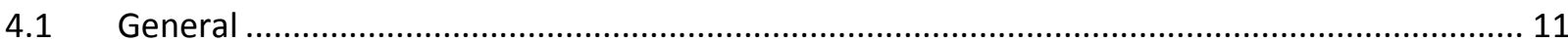

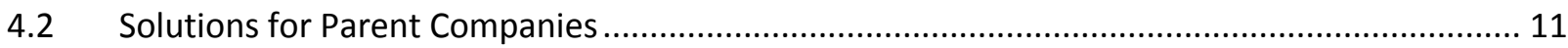

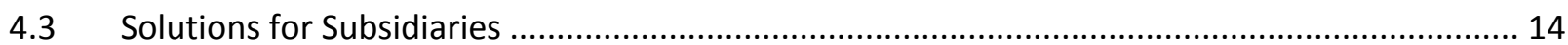




\section{Introduction}

The Commission's action plan of December $2012^{2}$ announced an initiative on simplified communication of a group's structure to investors (pp. 14 et seq.). This announcement is based inter alia on the Report of the Reflection Group from $2011^{3}$ (pp. 68 et seq.), which recommends making basic information on the group structure readily available to investors and presenting that information in an investor-friendly manner.

\section{State of Play}

Rules on information on groups can be encountered both at EU level and at the national level.

\subsection{State of Play at EU Level}

EU legislation already contains various references to information about groups, both for listed and unlisted companies.

\section{i) Accounting Directives}

Directive 2013/34/EU of 26 June 2013 on the annual financial statements, consolidated financial statements and related reports of certain types of undertakings ${ }^{4}$ contains rules for both the parent company and the subsidiary.

For the parent company, Art. 17 (1) (g) Directive 2013/34/EU provides for the notes to the financial statements of medium-sized and large undertakings to include "the name and registered office of each of the undertakings in which the undertaking ${ }^{5}[\ldots]$ holds a participating interest, showing the proportion of the capital held, the amount of capital and reserves, and the profit or loss for the latest financial year of the undertaking concerned for which financial statements have been adopted". A participating interest means an interest creating a durable link between the undertakings, which is presumed to exist where it exceeds a percentage threshold fixed by the Member States which is lower than or equal to $20 \%$ (Art. 2 (3) Directive 2013/34/EU). In effect, the accounting rules lead to the disclosure of direct subsidiaries (not of the entire group), but also of substantial holdings in other companies, which do not enable the company to exercise a dominant influence.

The notes to the consolidated financial statements contain further information on the parent company:

- Art. 28 (2) Directive 2013/34/EU stipulates that the notes to those statements must set out the names and registered offices of all undertakings included in the consolidation, in addition to the proportion of capital held in these undertakings. Additionally, the notes have to state whether the

\footnotetext{
${ }^{2}$ Action Plan: European company law and corporate governance - a modern legal framework for more engaged shareholders and sustainable companies, $\operatorname{COM(2012)~} 740$ final.

${ }^{3}$ Report of the Reflection Group on EU Company Law, 5 April 2011 (http://ec.europa.eu/internal market/company/docs/modern/reflectiongroup report en.pdf ).

${ }^{4}$ OJ L 182, 29.6.2013, p. 19.

${ }^{5}$ Purely indirect holdings (via other subsidiaries) are not covered.
} 
undertaking has been included in the consolidation due to a direct or indirect holding or due to other factors (cf. Art. 22 (1), (2) and (7) Directive 2013/34/EU).

- Art. 28 (2) (d) Directive 2013/34/EU stipulates that the notes to the consolidated accounts must include information on companies, in which group members hold a participating interest. Thus, the consolidated accounts cover both direct and indirect holdings.

Obviously, under the EU accounting regime, information in the consolidated accounts of the parent company contains information on groups. However, some points have to be made.

- First, the Directive makes consolidation mandatory only for companies in which the parent has the power to exercise or actually exercises a dominant influence or control due to a holding of more than $50 \%$ of the voting rights. The actual exercise of a dominant influence on the basis of a holding below that threshold only triggers the obligation to consolidate accounts if the Member State chooses to implement such a rule (cf. Art. 22 (2) Directive 2013/34/EU). Such companies may only be included in the list of companies in which the parent holds a participating interest (or not even recorded if the direct or indirect holding is below 20\%).

- Second, the information only contains a list of companies - including the reasons for consolidation without any description or visualisation of the group structure.

For the subsidiary, the notes to the financial statements of medium-sized and large undertakings have to include the name and the registered office of the undertaking which draws up the consolidated financial statements of the largest body of undertakings of which the undertaking forms part as a subsidiary undertaking (Art. 17 (1) (I) Directive 2013/34/EU). Additionally, the notes have to include the name and registered office of the undertaking which draws up the consolidated financial statements of the smallest body of undertakings of which the undertaking forms part as a subsidiary undertaking (Art. 17 (1) (m) Directive 2013/34/EU).

In general, this provision is not designed to publish control structures but rather to give guidance as to when the interested public is entitled to have access to consolidated statements. Therefore, it covers cross-border groups as long as the parent is subject to the obligation to consolidate accounts. Additionally, there is no information on groups in the accounts of subsidiaries which are small undertakings within the meaning of Directive 2013/34/EU.

\section{ii) International Accounting Standards}

For the parent company's consolidated accounts IFRS 10 stipulates the conditions which lead to mandatory consolidation. The guiding principle is control. The relevant (broad) definition of control is contained in IFRS 10.6: "An investor controls an investee when it is exposed, or has rights, to variable returns from its involvement with the investee and has the ability to affect those returns through its power over the investee."

IFRS 12 contains disclosure provisions aiming at improving the information about the subsidiaries that are consolidated. Special emphasis is placed on the nature and risks involved with the parent's investment in other companies and their financial effects on the parent (IFRS 12.1). Especially, an 
entity shall disclose the composition of the group (IFRS 12.10 (a) (i)) and significant judgements and assumptions it has made in determining that it has control of other entities included in the consolidated accounts (IFRS 12.7 (a)). The extensive information requirements focus on financial aspects (e.g. according to IFRS 12.14 the entity has to disclose any duty to provide financial support to its subsidiaries), but do not look at operations or governance structures.

Under IAS 27.16, a parent has to include a list of significant investments in its subsidiaries and associates in its separate financial statements, including the name of those investees, the principal place of business (and country of incorporation, if different) of those investees, and its proportion of the ownership interest (and its proportion of the voting rights, if different) held in those investees.

According to IAS 1.138 (c) any entity shall disclose in its notes the name of its parent and the ultimate parent of the group. Similarly, IAS 24.13 on Related Party Transactions obliges any entity to disclose the name of its parent and the ultimate controlling party, irrespective of whether there have been transactions between them; the definition of control is the one contained in IFRS 10.6 cited above. Thus, subsidiaries drawing up accounts according to International Accounting Standards have to disclose the identity of the ultimate controlling party, irrespective of whether this is a company, a natural person or any other entity.

\section{iii) Capital Markets Regulation}

Companies whose securities are admitted to trading on a regulated market in a Member State are subject to additional requirements. From the point of view of a subsidiary:

- According to Art. 9 of Directive 2004/109 (as amended by Directive 2013/50/EU6) (Transparency Directive) shareholders have to disclose if as a result of acquisitions they hold at least $5 \%, 10 \%, 15 \%$, $20 \%, 25 \%, 30 \%, 50 \%$ or $75 \%$ of the shares with voting rights; the information is made public. Thus, the disclosure focuses on the abstract voting power, but does neither look at whether that voting power is actually used nor cover instances where control is exercised without any acquisition touching a threshold. In other words, disclosure covers shareholdings, but not control structures.

- According to Art. 10 Directive 2004/25/EC (Takeover Directive), which applies to companies governed by the laws of Member States where all or some of their securities are admitted to trading on a regulated market in one or more Member States, the company's annual report has to include additional information on shares with special control rights; this information has to be included in the management report as part of the corporate governance statement (Art. 20 Directive 2013/34/EU). Of special interest for the purpose of this study is the disclosure of:

- $\quad$ significant direct and indirect shareholdings

- holders of any securities with special control rights and their description

- $\quad$ restrictions on voting rights

- known shareholders' agreements with restrictions on voting rights.

${ }^{6}$ OJ L 294, 6.11.2013, p. 13.

${ }^{7}$ OJ L 142, 30.4.2004, p. 12. 
Again, this information does not focus directly on whether the company is a subsidiary in a group, although it contains important information in that respect.

- According to Commission Regulation (EC) No 809/2004 ${ }^{8}$ as last amended by Commission Delegated Regulation (EU) No $759 / 2013^{9}$ (Prospectus Regulation) additional information on groups has to be disclosed in the prospectus. When issuing shares, ${ }^{10}$ the issuer has to disclose a brief description of the group and the issuer's position within the group, if it is part of a group and a list of the issuer's significant subsidiaries, including name, country of incorporation or residence, proportion of ownership interest and, if different, proportion of voting power held (Annex I No 7 Regulation 809/2004). If the issuer is a subsidiary, it has to state whether it is directly or indirectly owned or controlled and by whom and describe the nature of such control and describe the measures in place to ensure that such control is not abused (Annex I No 18.3). Finally, disclosure also covers information relating to the undertakings in which the issuer holds a proportion of the capital likely to have a significant effect on the assessment of its own assets and liabilities, financial position or profits and losses (Annex I No 25). Of course, the information is only disclosed upon issuing securities and not corrected after the prospectus has lost its validity.

\section{iv) Money Laundering}

The recent Directive 2015/849 on the prevention of the use of the financial system for the purposes of money laundering or terrorist financing ${ }^{11}$ (to be transposed by 26 June 2017) contains a general prohibition on such activities. One measure to make such a prohibition effective is increased transparency as to the natural persons who are beneficial owners in companies.

Certain obliged entities (especially credit institutions, financial institutions, auditors, notaries, lawyers) must take customer due diligence measures, especially to identify the beneficial owner of their customer, before carrying out certain transactions (cf. Art. 11 and 13 Directive 2015/849). For that purpose, Member States must ensure that corporate or legal entities established within their territory obtain and hold adequate, accurate and current information on their beneficial ownership (Art. 30 (1) Directive 2015/849); this information must be held in a central register, which is accessible for the authorities, obliged entities and anyone who can demonstrate a legitimate interest (Art. 30 (3) and (5) Directive 2015/849). A legitimate interest by a third person must concern the aims of the Directive, that is money laundering, terrorist financing and associated offences; thus, a creditor looking for the parent company of a subsidiary responsible for its debts or an investor wanting to know the ultimate controlling shareholder of a company will not be able to access the information unless the Member State has required the information to be made public.

Additionally, Directive 2015/849 does not concern itself with control, but (in line with its purposes) with beneficial ownership and, therefore, with natural persons (cf. Art. 3 (6)). Thus, if the company ultimately is controlled by another legal entity, which in turn does not have a controlling shareholder, this information will not be entered into the register. Of course, typical groups are not

\footnotetext{
${ }^{8}$ OJ L 149, 30.4.2004, p. 3.

${ }^{9}$ OJ L 213, 8.8.2013, P. 1.

${ }^{10}$ The minimum information on the issue of other securities is not analysed here.

${ }^{11}$ OJ L 141, 5.6.2015, p. 73.
} 
controlled by a natural person, but are generally led by corporate entities. Behind these corporate entities there could be one or more natural persons who own the shares.

\subsection{State of Play at National Level}

Legislative Acts of some Member States contain additional provisions, especially pertaining to controlling shareholders.

Art. 2497 bis Italian Codice Civile requires the company to indicate in its correspondence and official documents its parent company, i.e. the company with directing and coordinating powers over the company; both private and public companies are covered. Membership in a group is also required to be recorded in a special section of the Companies' Registrar, indicating the entities exercising management and coordination and those that are subject to these activities. Additionally, the subsidiary's notes to the financial statements have to include information on the relationship with the ultimate parent and its group (that presumably includes transactions). Additionally, for listed companies Art. 122 TUIF stipulates that agreements regarding the exercise of voting rights in such companies and their parent companies have to be published in extract form in a national daily newspaper and filed at the Companies Register; otherwise such agreements shall be void.

In Ireland, the subsidiary must disclose that it is availing of the exception to publish accounts as its parent has published consolidated accounts.

Similar rules on voting agreements are contained in Art. 19 of Portuguese Código dos Valores Mobiliários for listed companies.

The Draft of a new Spanish Commercial Code includes several sections/articles on disclosure about groups. Article 291-6 imposes a duty to inform the general meeting and the general public via the annual accounts on the entry into or exit from a group on the directors; the accounts have to include additional information on the functioning of the group. Article 291-7 imposes a duty to inscribe the group at the Companies' Register and to include that information on the corporate website, if any. Article 291-8 addresses corresponding liability issues.

3.

\section{Problems}

Stakeholders, and in particular creditors and investors have a legitimate interest in knowing the structure of the group to which the company belongs - either as a parent company or as a subsidiary.

Creditors and investors in a subsidiary may want to know which entity decides how the funds they have put at the company's disposal will be employed and which entity takes the ultimate decision as to the company's business policy; in case of unenforceability of a claim due to insufficient funds, they may want to clarify the role of the parent company in the subsidiary's demise - and, therefore, its identity.

Creditors and especially investors in the parent company may want to know the structure of the group the parent manages. They would like to have access to the main features of a company's 
group structure in a clear and investor-friendly manner, especially for subsidiaries which are material for the success of the group led by the parent company.

Finally, such information may be of interest to the public as well if this interest is not covered already by specialised EU legislation.

The current legislative framework at the European level does not meet these expectations entirely:

As far as the parent company is concerned, EU accounting rules lead to a disclosure of the names of entities in which the company holds a participating interest, which do not necessarily have to be subject to the control of the company; the consolidated accounts will only disclose participations of more than $50 \%$ of the voting rights if the Member State has not implemented a duty to consolidate if a dominant influence exists below that threshold. In all cases, accounting rules only cover the identity of the subsidiaries and the shares held by the parent company, but no further information or visualisation. Prospectus rules for listed companies contain further information, but no general duty to update such information without a further offer of securities.

The investors in and creditors of the subsidiary do not receive any information if the subsidiary is a small undertaking within the meaning of Directive 2013/34/EU. Only medium-sized and large undertakings have to disclose the company drawing up the consolidated financial statement. This helps, but does not cover all types of group as parent companies with a holding of less than the majority of shares with voting rights. IFRS 24 contains additional and far reaching disclosure rules, which, however, are only applicable if the subsidiary draws up accounts according to International Accounting Standards.

ICLEG thinks that this situation should be improved in order to strengthen the information available to stakeholders, and in particular to investors and creditors in both the parent and the subsidiary. Improved information will lead to less insecurity about who ultimately controls the group. That, in turn, can lower the cost of attracting both equity and debt capital (via a lower risk premium) if the parent is a respectable entity; even suppliers may be ready to extend credit more easily if they know more about the company's position in the group. Such mandatory disclosure would help the group member to convey information about its situation in the group to creditors and investors in a standardised manner. Of course, these advantages are not easy to measure; it is generally very hard to prove a causal link between particular disclosure requirements and reduced cost of capital. In order to avoid burdening companies with substantial costs in exchange for non-quantifiable advantages, one should try and keep the information requirements as simple as possible.

ICLEG is not alone in perceiving these lacunae in the law:

- In 2011, the Reflection Group pointed out that "(a)/though there are numerous and detailed rules on group information, there is no rule requiring an annual report, corporate governance statement or company website to describe the main features of a company's group structure in a clear and investor-friendly manner."12 This situation has not changed in recent years. The Reflection Group suggested that the Corporate Governance Statement should contain basic information on the group

\footnotetext{
${ }^{12}$ Reflection Group p. 75.
} 
functioning and management. This approaches the issue of information on groups from the point of view of the parent company.

- The Forum Europaeum on Company Groups, a group of European law scholars, has recently published a policy paper on the management of cross-border company groups, ${ }^{13}$ which distinguishes between service companies with a purely auxiliary function in a group (e.g. as manager of a cash pool) and ordinary subsidiaries. It proposed that service companies be required to indicate their integration within a group and their service function in their firm name and in their letterhead, while ordinary subsidiaries be required to establish transactional reports about their business with other group companies. It also proposed that the parent should deliver a structural report, in the sense that it indicates the ties of ownership within the group and elucidates the governance system observed in the reporting period. ${ }^{14}$ The Forum thus advocates more transparency at the level of both the subsidiary and the parent.

\section{Solutions}

\subsection{General}

ICLEG does not support a complete overhaul of the current European information regime on groups as contained in the legislative acts described above. We do not think that EU legislation should introduce detailed information of a technical nature on groups. Additionally, we do not feel comfortable with introducing rules in the realm of company law drafted to facilitate the work of public authorities as company law should focus on rules designed to adequately balance the interests of (different classes of) shareholders, creditors and other private stakeholders; these groups should be the primary addressees of any additional information.

Recommendation 1: The European information regime on corporate groups should not include detailed information of a technical nature.

However, ICLEG suggests that the Commission should evaluate taking action to supplement the current information regime on corporate groups in two different areas, namely information on the group for shareholders and creditors of the parent company on the one hand and for shareholders and creditors of the subsidiary on the other.

ICLEG is of the opinion that these issues should be put to stakeholders to get a broader spectrum of opinions. Especially, the interested public should be consulted on the following suggestions for legislative action:

\subsection{Solutions for Parent Companies}

The group structure is of importance to investors in the parent company. Knowledge of the isolated holdings as such is not sufficient; rather, ICLEG believes that investors want to have an overview of the structure of the group. However, a detailed analysis of the group functioning would be overly burdensome for the companies and, due to its complexity, would probably not be very useful to all

\footnotetext{
${ }^{13}$ European Company and Financial Law Review 2015, 299.

${ }^{14}$ Ibid. p. 305.
} 
but the most sophisticated investors. Therefore, ICLEG endorses the idea brought forward by the Reflection Group that companies should provide basic information on the group functioning and management.

Given the proposed focus on investors in the parent company and the fact that providing such information could be burdensome for small and medium-sized enterprises, the majority of ICLEG members think that the obligation to provide such information should be limited to companies listed on a regulated market. Additionally, the principal source of finance for unlisted companies is likely to be banks, which are well able to ask questions and obtain information from borrower companies about their structure. However, even with unlisted companies other creditors may be interested in such information. Therefore, the scope of applicability should be subject to consultation.

Such information is only partially covered by IFRS 12 , as (apart from the general duty to explain the composition of the group) these provisions focus on the subsidiary's effects on the financial position, financial performance and cash flows of the parent.

Recommendation 2.1: Companies should make public basic information on the group functioning and management in standardised visual form.

First, we therefore believe that some simplified form of information on the group structure should be given. Visualising the group structure in a diagram could improve information quality by providing comparatively clear information. Visualisation could help to avoid overly complex information (at least for less than highly sophisticated investors) and, thus, information overload, even if some accompanying texts may be necessary. ICLEG believes that compliance cost would be low as virtually all listed parent companies will have such visualisations for internal purposes, which can be adapted for disclosure. As one important benefit of such disclosure would be standardisation, i.e. improving comparability with other companies, any visualisation requirements like diagrams should be carefully designed and implemented having this key goal in mind.

Of course, such a visualisation may not be able to include all subsidiaries, but may have to concentrate on the principal subsidiaries. ICLEG suggests that the Commission consult on how to define principal subsidiaries as materiality could be described e.g. from a financial or from an operational point of view.

One key aspect of any envisaged piece of legislation in this area would be to determine the criteria for standardisation and the responsible body for setting up such standards. If it is decided that it is not feasible to rely on market practice alone and that a standard setter is needed, we think there should be requirements for the standard setter to consult with both those entities for which it would set standards and those who would be users of the standardised visual information.

Second, ICLEG thinks that the parent company should disclose whether it is potentially liable for any debts of its subsidiary either due to the type of company or due to contractual arrangements, such as sureties or comfort letters. Such an obligation exists under IFRS 12, but could be introduced for unlisted companies as well, which could require publication in the company's financial 
statements, but could also make use of other methods of publication as addressed in Recommendation 2.3 .

Third, one could envisage including additional information, e.g. on the subsidiaries' functions in the group or on financial relationships within the group (cash pooling, transfer pricing etc.). Whether such additional information is to be included should be put to the stakeholders for consultation.

Recommendation 2.2: Companies should inform investors in a simplified manner of the group structure, especially by visualisation. Additionally and in cases not already covered by IFRS 12, the parent company should disclose whether it is potentially liable for any debts of its subsidiary. Stakeholders should be consulted whether any additional information should be included such as information on the subsidiaries' functions in the group or on financial relationships within the group.

Current European Union legislation does not address the issue sufficiently. As shown above, the direct or indirect holding as such and the reason for consolidation have to be included in the notes to the financial statements of the parent company; additionally IFRS 12 calls for information on the financial impact of the subsidiary. If companies include more detailed information on their group they do so without any obligation under EU accounting rules.

ICLEG suggests that the Commission consults on the way for implementing such a proposal. At least three possibilities come to mind:

1. There may be non-binding ways in which such changes can be encouraged. A group comprising companies, investors, regulators and other interested parties could provide examples of good practice on information about groups and publicise these to encourage other companies to adopt them. This could partially be achieved within the framework of IFRS 12 (especially as to the composition of the group, but probably not on its management) and help in providing information that investors really want, whilst offering sufficient flexibility for different sorts of companies. Additionally, such an approach could be strengthened by an accompanying document from the Commission (e.g. a Recommendation).

2. European legislation could also mandate that such information be disclosed in the company's Corporate Governance Statement as part of the (consolidated) management report on a comply-or-explain basis. Legislation could either prescribe the information to be published in detail (in that case a good consultation process could avoid unnecessary or overly expensive legislative requirements) or could leave that to market practice (and, thus, to self-regulation by stakeholders). Alternatively, European legislation could require that certain information has to be disclosed in the notes to the annual report.

3. Publication on the parent company's website could also be made mandatory. In order to improve accessibility, European legislation could also consider a central website/database, which could hold such information; in that vein, even access via the 
(interconnected) Business Registers may be an option, which would probably require development of software for visualisation.

Recommendation 2.3: The Commission should consult on whether such information should be mandatory, given on a comply-or-explain basis in the Corporate Governance Statement or encouraged in a non-legislative manner. Consultation should also cover whether and to what extent the type of information to be provided should be included in EU legislation.

\subsection{Solutions for Subsidiaries}

ICLEG believes that for shareholders and creditors of the subsidiary the present situation on the European level is unsatisfactory. Stakeholders, and in particular creditors and shareholders of a company are interested, first, in whether a company they have given credit to or are invested in is subject to control by another entity and, second, in the identity of the controlling entity. That of course also holds true for those who are deciding whether to extend credit or to invest.

If such information is reliable, signalling effects may improve conditions of credit or equity finance for companies without a controlling shareholder or with an ultimate parent of good repute. While this may not be an issue for professional creditors (especially banks), for whom it may be possible to get the requisite information in other ways, it can be of importance to smaller creditors, especially those delivering goods or providing services with deferred payments, or business partners entering into long-term agreements with the company. As long as such information is not complex, small creditors presumably are able to process it; such processing could also be done indirectly by information providers like credit bureaus. This reasoning is equally applicable to listed or unlisted companies, even if the latter are private companies or SMEs.

In order to enable these stakeholders to make use of the information, access is a crucial issue. Currently, any information on the controlling shareholder is only made public in the annual accounts, which are not sufficiently accessible, at least for non-listed companies. In practice, access is especially difficult for small creditors, especially from other Member States.

Additionally, the accounts of small companies do not include information on their subsidiaries or on undertakings drawing up the consolidated accounts even if they are accessible. Finally, the obligation to consolidate accounts does not cover all cases in which the company belongs to a group, especially because Member States have made use of exemptions provided for by Directive 2013/34/EU.

Without doubt, the disclosure rules under IFRS 10 (disclosure of the immediate parent and the ultimate controlling party in the subsidiary's accounts) provide important information on control of the company, but only for entities drawing up accounts under International Accounting Standards. Under the Fourth Money Laundering Directive, companies are only required to keep information about individuals who are the beneficial owners of shares and, directly or indirectly, own or control the company; additionally, the public at large may not have access to information about the persons who control a company as a result of implementation of this Directive, as access to this information may be limited to persons who can demonstrate a legitimate interest (in addition to access by competent authorities, Financial Intelligence Units and obliged entities). 
Therefore, ICLEG favours introducing a new rule in European law which obliges companies to give information on the direct or indirect shareholder controlling the company ("ultimate parent").

Recommendation 3.1: The Commission should consider introducing an obligation to make public the identity of any direct or indirect shareholder exercising control over a company ("ultimate parent") and consult on this with stakeholders.

ICLEG is of the opinion that such a rule should not be restricted to cross-border groups, but should cover all groups even if purely national. Although a rule restricted to cross-border groups (with the possibility of a roll-out to purely national groups at a later stage) would be easier to justify in the European context, such a restricted regime would necessarily be incomplete and lead to different levels of information for different groups. Intervention for purely national groups can be justified as creating a level playing field for creditors and investors as far as information is concerned; Directive 2013/34/EU follows that approach.

For similar reasons and in line with national rules to that effect, we favour an approach that covers all companies, not just listed or public companies; creditors' information requirements are not dependent on the legal form. Therefore, IAS 1.138 (c) by itself is not sufficient, as most national companies do not apply IFRS. We think that compliance costs for the companies can be minimized by the design of the substantive rules.

Recommendation 3.2: Such an obligation should cover both national and cross-border groups, irrespective of whether the subsidiary is listed or not.

Such a rule has to deal with the question of definition of the entity that actually exercises control over the company. ICLEG believes that this should be an important issue in any consultation of stakeholders.

First, one could make use of the definition contained in the Art. 22 Directive 2013/34/EU, that is both the $50 \%$ threshold and, for the purpose of disclosure mandatorily, the actual exercise of a dominant influence on the basis of a holding below that threshold. However, for the purposes of disclosure this would have to include ultimate parents domiciled outside of the European Union. An advantage would be the low costs of compliance and the fact that market participants already are familiar with this definition. Of course, other definitions of control exist, such as the definition contained in Art. 3 of the EWC Directive 2009/38/EC ${ }^{15}$; whether this and similar definitions are adequate for the purpose of disclosing the "ultimate parent" has to be assessed separately.

Second, a new definition could be introduced. This could, as in Art. 2497 bis Italian Codice Civile, look at the company or entity whose direction and coordination activity the controlled company is subject to. One would have to decide whether to limit such a rule to undertakings with a direct or indirect shareholding in the controlled company; this would make the rule easier to apply, but may open up possibilities of circumvention as it does not look behind nominee shareholders. Of course,

\footnotetext{
${ }^{15}$ Directive 2009/38/EC of 6 May 2009 on the establishment of a European Works Council or a procedure in Community-scale undertakings and Community-scale groups of undertakings for the purposes of informing and consulting employees, OJ L 122, 16.5.2009, p. 28.
} 
market participants may be confused by yet another definition, which weighs against such an approach as long as there are no overriding reasons in favour of such an approach.

Recommendation 3.3: The Commission should consult on whether a new definition of ultimate parent should be introduced for the present purpose or whether an existing definition of control should be re-used.

ICLEG believes that the information to be disclosed should be limited and easy to understand; additionally, that helps to keep compliance costs low. The main piece of information is the identity of the controlling undertaking for the purposes set out above (cf. 3.). A visualization of the group structure on the level of the subsidiary is probably not necessary for information purposes; this would greatly increase compliance costs to the controlled entity without providing absolutely necessary information.

Alternatively, disclosure could additionally contain verbal information on group decision-making mechanisms. This narrative approach would most probably make disclosure more precise, but might increase compliance cost.

Recommendation 3.4: The Commission should consult on whether disclosure should be limited to the identity of the ultimate parent or also include verbal information on group decision-making mechanisms.

The controlled entity will have access to the information it is required to make publicly available. That will be comparatively easy as far as direct holdings are concerned, as the company usually will know its shareholders - especially if the shareholder exercises control. However, the company may not have access to information on indirect shareholdings.

Therefore, any rule has to impose a disclosure obligation on direct and indirect shareholders, both in their role as subsidiaries higher up the chain of command and as controlling entities. That has to include a duty to answer the company's questions.

This alone would not be sufficient, as it would be overly burdensome on subsidiaries if they had to monitor changes to existing control structures. For that reason, both former and new controlling shareholders ${ }^{16}$ should be obliged to notify their direct subsidiaries of any change in a control position, which then would have to be passed down the chain of control to all subsidiaries affected. As this is a rather simple binary information compliance cost for these entities should be low.

Recommendation 3.5: Any disclosure rule should oblige a direct parent company to inform any direct subsidiary of any change in control in relation to it and of any change in relation to any of its parent companies of which it has been notified.

A final issue as regards the substance is the method of making the information available. ICLEG wants to draw attention to the fact that disclosure is not made for the purpose of facilitating the bringing of claims against parent companies, but for signalling purposes - which of course has

${ }^{16}$ Of course, any such instrument would also have to deal with the role of custodians. 
consequences for the method of disclosure: The information should be easily accessible for all stakeholders.

Legislation could oblige companies to include such information in the notes to the financial statements, ${ }^{17}$ as provided in IFRS 24.13 for companies drawing up accounts under International Accounting Standards. However, as explained above the financial statements may be hard to access, especially for small investors or creditors. Additionally, the notes are only updated once a year and cannot reflect changes during the financial year.

A more modern way of communication would be the company website. However, not all companies actually have a website. It would be probably be disproportionate to force SMEs to have a website for a very limited purpose only. Additionally, it is very hard to verify ex post whether such information was actually available at a certain point in time; to rely on the website exclusively does not seem appropriate. However, ICLEG could envisage obliging companies to include such information on their website if they have one.

Instead the Commission could consult on whether information on the ultimate parent should be entered in the national company register; the information could then be available via the interconnection of Business Registers. This is easy to update when a change of status occurs; additionally, in most jurisdictions it is easy to ascertain which information was included in the register at any point of time. This may be an appropriate approach for sophisticated investors or creditors, but more problematic for SMEs as creditors or private individuals as, in practice, they often do not have the means to access foreign business registers even though access is being constantly improved.

For these addressees disclosure in the company's correspondence, including electronic correspondence, (as foreseen in Italy; cf. 2.2) could complement the entry in the register. This push communication can be updated without substantial cost to the company (as in most cases stationery these days is not printed beforehand, but stored online). Stakeholders should be consulted on whether such constant information may give a wrong impression as to the parent company's liability and on how such a danger can be mitigated. Of course, the appropriateness of the method to be used depends on the disclosure requirements; it would not be practical to include detailed information in such a way.

Recommendation 3.6: The Commission should consult on the method of disclosure, especially whether disclosure should be made via the company website, the national company register, the company's correspondence or any combination of the above.

\footnotetext{
${ }^{17}$ Which would have the effect of supplementing the information on consolidation already contained in the notes.
} 


\section{Overview of Recommendations:}

Recommendation 1: The European information regime on corporate groups should not include detailed information of a technical nature.

Recommendation 2.1: Companies should make public basic information on the group functioning and management in standardised visual form.

Recommendation 2.2: Companies should inform investors in a simplified manner of the central group structure, especially by visualisation. Additionally and in cases not already covered by IFRS 12, the parent company should disclose whether it is potentially liable for any debts of its subsidiary. Stakeholders should be consulted whether any additional information should be included such as information on the subsidiaries' functions in the group or on financial relationships within the group.

Recommendation 2.3: The Commission should consult on whether such information should be mandatory, given on a comply-or-explain basis in the Corporate Governance Statement or encouraged in a non-legislative manner. Consultation should also cover whether and to what extent the type of information to be provided should be included in EU legislation.

Recommendation 3.1: The Commission should consider introducing an obligation to make public the identity of any direct or indirect shareholder exercising control over a company ("ultimate parent") and consult on this with stakeholders

Recommendation 3.2: Such an obligation should cover both national and crossborder groups, irrespective of whether the subsidiary is listed or not.

Recommendation 3.3: The Commission should consult on whether a new definition of ultimate parent should be introduced for the present purpose or whether an existing definition of control should be re-used.

Recommendation 3.4: The Commission should consult on whether disclosure should be limited to the identity of the ultimate parent or also include verbal information on group decision-making mechanisms.

Recommendation 3.5: Any disclosure rule should oblige a direct parent company to inform any direct subsidiary of any change in control in relation to it and of any change in relation to any of its parent companies of which it has been notified.

Recommendation 3.6: The Commission should consult on the method of disclosure, especially whether disclosure should be made via the company website, the national company register, the company's correspondence or any combination of the above. 